Sultan Qaboos University Journal of Arts \& Social Sciences

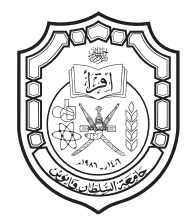

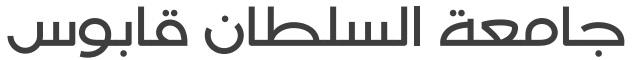

مجلة الآداب والعلوم الاجتمأعية

\title{
Salalah :Perfume Capital of Arabia A Visitor Profile Study
}

\author{
Mohamed Abdul-Ghani \\ Assistant Professor, \\ Department of Tourism \\ College of Arts \& Social Sciences \\ Sultan Qaboos University
}




\title{
Salalah: Perfume Capital of Arabia \\ A Visitor Profile Study
}

\author{
Mohamed Abdul-Ghani
}

\begin{abstract}
In an effort to develop and implement effective promotion strategies for tourism in a specific destination, it is important to describe the characteristics and behaviors of visitors to the destination as well as monitor changes and trends in the region's tourism industry. One of the most common methods to accomplish this objective is to conduct a visitor's profile study. This study aimed to determine the characteristics of visitors to the city of SALALAH as a whole.

This study viewed SALALAH tourist profile with regards to two major key variables namely: the tourists' socioeconomic characteristics and the tourists' behavioral characteristics. While the tourists' socio-economic characteristics are often described in terms of age, sex, education and income levels, behavioral characteristics include tourists' motivation, attitudes, needs and values. These characteristics are essential not only because they all influence the magnitude, frequency, and kind of interaction with the physical attributes of the tourism destination and its people but also because they play a crucial role in contributing to the tourist decision-making processes.
\end{abstract}

Key Words: Salalah, Visitor's Profile, Tourism Promotion, Sultanate of Oman.

\section{دراسة أنماط الزائرين لملدينة صلالة "عاصمة العطور فى شبه الجزيرة العربيةه}

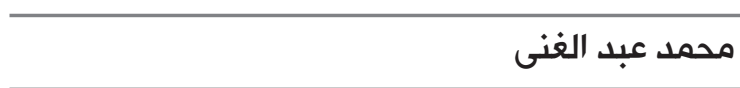

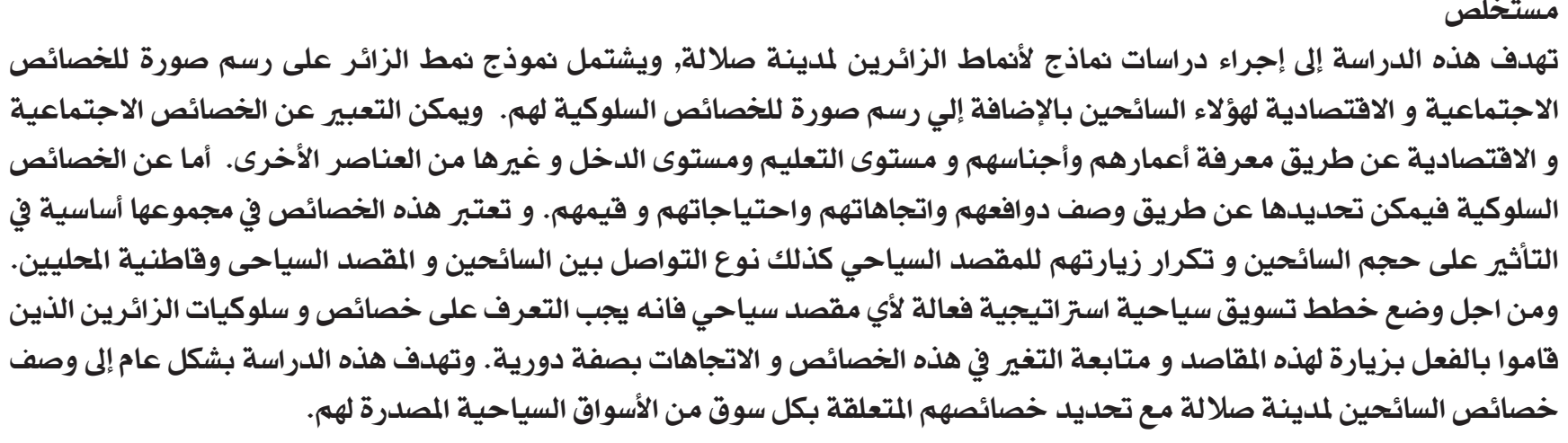
الكلمات الدالة: صلالة، دراسة أنماط الزائرين، ترويج السياحة، سلطنة عمان 


\section{Introduction}

Tourism in Oman has witnessed a robust growth over the years. According to the Tourism Authority represented by the Ministry of Tourism, in fact, leisure visitor arrivals almost doubled between 2000 and 2010 due mainly to Oman's natural landscape which includes a long coastline, majestic deserts, several mountain ranges and a lush southern region. An increase of awareness among Omanis, new hotels and resort facilities and the development of more destination activities also helped drive tourist arrivals. A mention in Condé Nast Traveler is the kind of endorsement and publicity money can't buy and is going a long way in raising Oman's profile among its target market. This rise in tourist arrivals has created opportunities for all tourism sectors, from travel agents and tour operators to accommodation and transportation providers. (Euro-monitor, 2007)

Thus, a development boom is underway in Oman. Inspired by the large-scale building and massive tourism inflows in Dubai, the Sultanate announced several mega projects, including the Wave - a mega mixed-use development and the Muriya tourism project (a joint-venture between the government and Egypt's Orascom). Oman's development boom is concurrent with the government's push and investments to develop tourism. All these investments, directly or indirectly, have the potential of giving a boost to the Omani tourism industry. Resorts and other development projects are important increasing tourist traffic to Oman. The increased business activities, driven by the larger projects, are boosting business arrivals to the country, while the presence of more hotels and resorts is attracting leisure tourists. Hence, these development projects impact positively on the hotels business in both leisure and business segments.

Oman's government is one of the most proactive bodies in the region in terms of promoting tourism development. The government is active in encouraging private and foreign participation in the market, and is a co-investor in many tourism projects. It embarked on a promotional and marketing blitz, appointing destination marketing agents in key markets (UK, Germany, France) as well as participating in tourism fairs and conventions. Furthermore, a Memorandum of Understanding was signed between the UAE and Oman to increase flights on the Sharjah - Muscat - Sharjah route. Under the Memorandum of Understanding, flights between the two countries have increased to eleven a week on the Sharjah Muscat route and four a week on the Sharjah - Salalah route. This Memorandum was signed to meet the rising demand of flights between the two countries. (Euro-monitor, 2007)

\section{The New tourism Hotspot for Gulf Tourists}

Oman is witnessing an important growth in the number of visitors coming from the Middle East, especially from the Gulf Cooperation Council (GCC) countries. In 2010, visitors from the UAE, Saudi Arabia and Bahrain were expected to increase exponentially. Oman's tourism authority identified regional travelers as a key emerging market. As a result, officials are putting more effort into promoting Oman destination offering to its neighbors. (Euro-monitor, 2007)

\section{Salalah: Perfume Capital of Arabia}

Salalah is the capital and seat of the governor or Wali of the southern Omani province of Dhofar. The population of Salalah is 178,469 as of 2005 . Salalah is located at $17.02^{\circ} \mathrm{N}, 54.09^{\circ} \mathrm{E}$. Salalah is the second largest city in the Sultanate of Oman and a traditional stronghold and birthplace of the Sultan, Qaboos bin Said. The Sultan does however visit Salalah fairly regularly to meet with influential tribal and local leaders. His last visit to Salalah was in 2006 and before that he visited it in 2002. (Salalah, 2013)

Salalah is served by an airport, mainly catering domestic flights from Muscat and some regional cities such as Kuwait, Dubai, and Doha. Seasonal flights, some of which from as far away as Sweden, can be seen though during the Khareef season (Fall season), the peak of the tourist season. Oman Air, the domestic carrier, currently operates several daily flights to Salalah Airport from Muscat.

Salalah, despite lying in the Arabian desert, enjoys a temperate climate through most of the year. The city is also subjected to the south-east monsoons. This period (late June to early September) is known as the khareef season. Visitors from across the Persian Gulf flock to Salalah to enjoy the monsoons and avoid the harsh heat faced by the rest of the region during the same period. Also in this period, the city's population nearly doubles and various fairs are organized such as those at Ittin. The city has a large expatriate community, mainly from India, as well as a private Indian School, known as the Indian School Salalah.

The city of Salalah is known as the "perfume capital of Arabia.» It is a popular tourism destination due 
to the natural attractions of the Smahan mountains (Jabal Smahan, in Arabic) and abundant stands of frankincense trees lining mountain stream courses. Around the city and into the mountains the countryside is lush and green with the vegetation supporting herds of cattle. The climate supports wildlife often more commonly associated with East Africa, such as leopards and hyenas. The beaches and coastline are also major attractions for scuba diving and bird watching.

Salalah is a city of antiquity, boasting both the ruins of a palace reputed to have belonged to the Queen of Sheba and the resting place of the biblical prophet Job in the nearby Jabal al Qar. It is also the alleged resting place of Nabi Imran, father of the Virgin Mary. Modern Oman is also represented by the Port of Salalah, located approximately $15 \mathrm{~km}$ to the southwest of the city. The strategic location of this port has made it one of the major entry points to India, the Middle East, and Africa. Maersk runs the Salalah Port which is an important centre of shipping in the area. (Salalah, 2013).

\section{Aim of the Study}

This study aims to determine the common characteristics of visitors to Salalah. In an effort to develop effective marketing strategies for a specific tourism destination, it is important to describe the characteristics and behaviors of visitors to the destination as well as monitor changes and trends in the region's tourism industry. One of the most common methods to accomplish this objective is to conduct a visitor's profile study. The tourist profile can be viewed under two major categories: the tourists' socio-economic characteristics and the tourists' behavioral characteristics. The socio-economic characteristics of tourists can be described in terms of age, sex, education, and income levels. Behavioral characteristics include motivations, attitudes, needs and values of tourists. These characteristics are essential because they all influence the magnitude, frequency, and kind of interaction with the physical attributes of the tourism destination and its people. They are also of crucial importance in contributing to the tourist decision-making processes.

\section{Literature Review}

Many scholars maintain that the tourist profile variables should be classified under two major categories: the tourists' socio-economic and behavioral characteristics.

\section{Tourists' Socic-economic Characteristics}

Studies have shown that age, education, income and previous experiences influence attitudes, perceptions and motivations and affect decisions. Clearly, individuals with low disposable incomes are less likely to pursue travel arrangements which involve first-class air fares, expensive hotels, and costly restaurants, than those who are wealthier. Few elderly travelers are likely to participate in mountain climbing or visit night-clubs. Relationships between socioeconomic variables and participation in recreation and travel are well documented in the literature. However, it should be noted that such relationships do not really explain recreational behavior and that it is not possible to predict what people will do merely from knowledge about their socio-economic characteristics. (Mathieson and Wall, 1992)

\section{Tourists' Behavioral Characteristics}

Tourists' motivation, attitudes, needs and values are of crucial importance in contributing to their decisionmaking processes. Motivation to travel are related to expectations, needs and wants. These, in turn, reflect tourists' personalities and socio-economic profiles. Although highly interrelated, and for the sake of simplicity, each variable was investigated separately as follows:

\section{(1) Needs}

A person's needs is an internal condition that arises from the lack of something which, if present, would tend to further the well-being of that individual. Needs may be emotional, spiritual or physical. Collectively, they are determinants of tourist motivation. An individual's need for change, new experiences, adventure and aesthetic appreciation may all be satisfied by travel and tourist activity. (Mathieson and Wall: 1992)

\section{(2) Motivation}

Wahab (1975: 44) described travel motivations as: "one of the most basic and indispensable subjects in tourism studies.» «Ignoring it or passing lightly over it», he insists, «would defeat the whole purpose behind tourist development plans.» In early times, people traveled for reasons which were more easily identified than the reasons inducing modern tourists to travel. These included the search for food, water and shelter, for economic and territorial gain as well as religious devotion. Few people traveled for sheer pleasure. Modern tourists travel essentially for pleasure but 
may do so for a number of additional reasons. These consist of push factors, such as the desire to escape the daily living and working environment, pollution and traffic congestion of cities on the one hand, and pull factors, such as the attractions of the destination, visiting friends and relatives, playing or watching sports. (Mathieson and Wall: 1992)

Tourist motivation is far more complex than these classifications suggest. Motivation operates at a general level when they induce a person to travel. They become more specific when a tourist is urged to visit certain destinations or select a particular activity or mode of transport. Tourist motivation is diverse and may be incompatible. Travelers' motivation to visit places on business, for health reasons, or to see relatives may be largely predetermined. In such circumstances, the traveller's choice of destination is more likely to be beyond the control of the traveler and commitment to the destination may be weak. This has obvious implications for the likelihood of return visits.

\section{(3) Travel Awareness}

Potential tourists may be motivated to travel but, unless they are informed about what opportunities are available, they may be unaware of the means of meeting their requirements. Tourists' awareness of destinations, facilities and services depends on the availability of information and the credibility of its source.

Information on the tourist product is transmitted to potential tourists through both formal and informal sources. Formal sources include magazines, travel brochures, advertisements on radio and television, and discussions with travel intermediaries. Informal sources refer to comments obtained from relatives, friends or other travelers.

A tourist image, or impression, is conjured up from the information received, as interpreted through the personal and behavioral characteristics of the tourist. Image is defined as: "an expression of all objective knowledge, impressions, prejudices, imaginations and emotional thoughts an individual or group have of a particular object or place». (Mathieson and Wall: 1992)

The decision to travel precipitates a series of subsequent decisions, including choice of destination, mode of travel, length of stay and type of accommodation. The images of potential destinations are important to these decisions. The quality and range of services may be similar in a number of destinations but their images may differ. These differences may be the decisive factors in the choice between travel opportunities. The images of destinations may differ greatly from reality. The larger the difference between image and reality, which is between expectations and experience, the more likely the tourist is to be dissatisfied. Therefore, information made available to the tourist should have a firm basis in reality. (Mathieson and Wall, 1992).

A number of possible destinations may appear to satisfy the personal requirements of the potential traveler. Each alternative is evaluated according to its compatibility with a number of criteria which are indicated under the three broad headings: generation point characteristics, trip features, and destination resources. (Mathieson and Wall, 1992).

\section{3.a. Generation point characteristics}

Attributes of the place of residence, or generation point characteristics refer to considerations regarding home, work and family. They might encompass willingness to leave work unfinished around the house, the responsibilities to take children, travel, select destinations, enjoy, make arrangements for the care of family pets, for job replacements, and for the welfare of family members in the absence of the traveler. Travelers may not select destinations at great distances because of these deterrents, nor will they stay very long if their jobs demand their services. Trips are less likely to be multi-destinational if young children are to be included in the party. (Mathieson and Wall: 1992)

\section{3.b. Trip features.}

These include such factors as distance, duration of stay in one or more destinations, time constraints, trip cost and value for price, party size, perceived risk and uncertainty at the destination, and confidence in travel arrangements and travel intermediaries;

\section{3.c. Destination resources}

The features of potential destinations play an important role in the assessment of alternatives and in the final choice of a destination. These include types of attraction, the availability and quality of services, environmental conditions, the attributes of the host population and their political organization. In addition, the potential tourist is likely to consider the practical barriers of entering a destination (customs, immigration and security inspections), the accessibility of the destination and of other complementary 
attractions, and host attitudes towards tourists. (Mathieson and Wall: 1992)

\section{(4) Attitudes}

Tourist attitudes are important components in travel motivation, reflect past experiences and can serve as indicators of the attractions of traveling and visiting distant places. Information on many of the above concerns are revealed to the potential tourist through the formal and informal information sources mentioned earlier. Knowledge about some travel aspects can be gained from earlier travel experiences, and some considerations may be unperceived.

The combination of trip features and destination resources constitute the information base upon which decisions concerning destinations, modes of travel and activities are formulated. Generation point characteristics place constraints upon these decisions. Following these decisions, final travel arrangements can be made. After returning from a trip, tourists recollect and evaluate their total travel experiences. These experiences provide the basis for subsequent travel decisions, whether to the same destination or to a different one. (Mathieson and Wall: 1992)

\section{Methodology}

In order to obtain highly accurate data about the characteristics of visitors to Salalah, a survey was designed and distributed to intercepting visitors of Salalah at various locations. Locations included different types of accommodations, travel agencies, airport, and Khareef Salalah Festival site during the summer of 2007 . The survey consisted of two pages and included 25 questions. It included questions to determine trip characteristics, demographics, and satisfaction levels of visitors to Salalah. Due to the international nature of this study, the survey instrument was translated into two languages (English and Arabic). The survey was distributed to visitors who felt more comfortable answering questions in their native language. To help capture more international visitors, more valid and reliable information was obtained from them when they could read the questions in their native language. The characteristics of visitors included within the survey instrument and which have implications for carrying capacity and the nature of visitor impacts included the following:

1- The socio-economic characteristics of visitors.

These include:

- age and sex profiles;

- income levels;
- availability of spending money;

- motivation,

- attitudes and expectations;

- perceptions of resource quality;

- racial and ethnic backgrounds;

- overt behaviors.

Together, these variables contribute to an interpersonal style;

2-The level of use.

- number of visitors,

- their distribution in space and time and, hence, visitor density are of obvious importance;

3- The length of stay.

4- The types of tourist activity.

5- The levels of tourist satisfaction.

Each of the above visitor characteristics is important because they all influence the magnitude, frequency and kind of interaction with the physical attributes of the destination and its people. Visitors' intercepts were conducted with approximately 200 visitors for a period of one week. Only the results of a 100-completed surveys were presented in this article.

\section{Results and Discussion}

Salalah Visitors' Levels of Education

Fifty-four percent of visitors had different level of education while forty-six were not declared. One percent of visitors had Master Degrees, thirty-seven were holding Bachelor Degrees, thirteen percent finished High School, and three percent only had middle school certificate.

\section{Ages of Visitors to Salalah}

Visitors' ages varied between 1-15 years to more than 65 years. The majority were between the age of 1-15 (39\% of the total number of visitors) and $25-44$ (29\% of the total number of visitors). It was clear that this majority were comprised of families with children. Another considerable percentage of $26 \%$ were between the age of 16-24 young professionals and couples. Five percent of visitors were between the age of 45-64 years and one percent of visitors were over the age of 65 years.

\section{Purpose of Visit to Salalah}

The first main reason for visiting Salalah was for holiday, leisure, and recreation with $72 \%$ of visitors. The second most important purpose was to visit friends and relatives (VFR) with $16 \%$. Visiting Salalah for business came third with $4 \%$ of the total number 
of visitors and visiting for shopping came fourth with an equal amount of visitors (4\%). Visiting for the purpose of education or training comprised only $2 \%$, while visiting for conference attendance, meetings, incentives, and exhibition (MICE) came last with a very low percentage (1\%).

\section{Trip Planning Horizon}

The duration of trip planning horizon for the respondents were very interesting since the biggest majority of 69 percent planned their trips to Salalah within a period of one to 15 days. Twenty-two percent only planned their trips between 15 days and a full month. Four percent only planned their trips between one month and three months. The last 5 percent have planned their trips for more than three months.

\section{Length of Stay in Salalah}

With regard to the length of stay of visitors to Salalah, only one percent of respondents spent one night only. Thirty-three percent spent two to five nights. The survey results show that a large number of vistors planned to stay for more than 5 nights in Salalah.

\section{Types of Reservations to Salalah}

To rank the type of reservations used to book a trip to Salalah, travel agents came first, followed by reservations through airline companies (mainly OMAN AIR, the national carrier for the Sultanate of Oman), and the least type of reservations used was through the internet travel trade intermediaries. A majority of 53 percent indicated that they had no prior reservations arrangement, which might pose a serious forecasting problem to accommodation establishments in Salalah.

\section{Means of Transportation to Salalah}

The most common mode of transportation used to get to Salalah was privately owned automobiles (5\%). The second most common mode was airplanes (40\%). Buses were only used by 3 percent of the respondents, while one percent only used rented automobiles.

\section{Types of Accommodation Used by Visitors to Salalah} Types of accommodation hosted the visitors surveyed varied from hotels (63\%), apartment hotels (18\%), staying with relatives and friends (16\%), furnished apartments (2\%), owned apartments (1\%). Camping was not a chosen type of accommodation by all the visitors surveyed.
Visitors' Activities in Salalah

The top four activities practiced by most visitors to Salalah were water springs, attending khareef festival, wadi bashing, and relaxing on the beach. Seeing caves, shopping, and enjoying wild life and nature were practiced by almost half of the respondents surveyed. Only thirty-seven percent visited forts and castles and thirty-four percent accompanyied children to parks and gardens.

Sources of Information Obtained by Visitors about Salalah

The majority of visitors to Salalah have indicated their previous visits to the destination (65\%). Thirtynine percent of visitors received recommendations from relatives and friends to visit Salalah. Twentythree percent were influenced by television to make the decision to visit Salalah. Less than ten percent of visitors surveyed relied on holiday and travel brochures, the internet, newspapers, guide books, travel agents, magazines, and the radio for obtaining information about Salalah before their visit.

\section{Segmentation of Visitors to Salalah}

The majority of visitors surveyed were considered family segment ( $83 \%$ of respondents). The second rankings for segments were friends segment (26\%). Only 9 percent of respondents traveled alone to Salalah which might be for business purposes. No organized tour groups were detected from the respondents. This might indicate the nature of regional and local visitors' habits in traveling with family by private cars specially when combined with the major mean of transportation used.

Factors Affecting the Decision to Travel to Salalah The top four factors affecting the decision to travel to Salalah ranked according to importance were as follows; (1) Climate, (2) People, (3) Culture and History, and (4) Beaches. The least important factors were (5) Prices, (6) Proximity to original destination, (7) Activities, and (8) Places of Business.

Rating the Salalah Experience

(1) Hospitality, (2) Safety, and (3) Accommodation were raked positively at the top in describing the Salalah visit experience. (4) Cleanliness, (5) Restaurants, (6) Availability of information about tourist sites and attractions were ranked lower than the previous factors. (7) Taxis and buses to move around the place, (8) shopping, (9) amount and (10) quality of available 
activities for the tourists needed more attention. (11) Tourist guides were considered one of the major areas in need of improvement to enhance the Salalah positive experience.

\section{Nationalities of Visitors to Salalah}

United Arab Emirates nationals represented 39 percent and ranked number one nationality visiting Salalah. Saudi Arabia nationals ranked second in terms of visiting Salalah (20\% of respondents). Omani locals (14\%) were at the third place in terms of nationality visiting Salalah followed by Indian nationals (11\%). It should be noted that Indian nationals were working expatriates residing in Oman and UAE. Kuwaiti, British, Bahraini and Qatari nationals traveled the distance to visit Salalh. Iraqi, Qatari, Polish, and Philippino nationals who visited Salalah were expatriates living in the UAE.

\section{Current Places of Residence of Visitors to Salalah}

Fifty-two percent of visitors surveyed resided in the UAE. Twenty percent of respondents resided in Oman and fourteen percent of visitors resided in KSA. The remaining $12 \%$ of respondents resided in Kuwait, the United Kingdom, Bahrain, India, Qatar, and the United States of America. It was quite clear that the majority of visitors to Salalah came from Oman as domestic tourists and from the UAE and KSA as intra-regional tourists.

Levels of Visitors' Satisfaction with Salalah

Sixty-five percent of visitors were highly satisfied with their visit to Salalah. Thirty-one percent of visitors were satisfied. A total of $96 \%$ of visitors, a great amount of respondents indicated a high level of satisfaction by their visit. The remaining numbers of visitors, forming only 5 visitors were neutral. No dissatisfaction sentiments were recorded by any of the surveyed respondents.

\section{Are You Planning to Come Back to Salalah?}

Respondents were asked whether they were planning to come back to Salalah or not, $79 \%$ indicated their willingness to visit Salalah again. Twenty percent expressed their wish to visit Salalah. Only one respondent indicated clearly that coming back to Salalah was not an option.

Would You Recommend Salalah to Anybody?

A final question was raised and the respondents surveyed were asked whether they would recommend Salalah to anybody? Eighty-seven percent of respondents were hundred percent sure of recommending Salalah to others. Twelve percent stated they might or might not recommend Salalah to others. The same person who claimed he would not visit Salalah again has also shown no willingness to recommend Salalah to anybody.

\section{Visitors' Comments on Their Visit to Salalah}

The following comments were compiled from the last question of the survey asking respondents to write any suggestions or comments regarding their visit to Salalah. The number at the end of each comment indicates the frequency of each comment mentioned by the respondents. Hence the following:

-More restaurants for families near mountains, water springs, and wadis (mentioned 8 times),

- Dual (two-way) highway between Nizwa and Salalah and more lighting (mentioned 6 times),

- Good and clean hotels on green mountains (mentioned 5 times),

- Greater emphasis on cleanliness and sanitation of eating places and staff working there (mentioned 5 times),

- More rest rooms in attraction sites (mentioned 5 times),

- Villas on the beach needs improvement and over priced (mentioned 4 times),

- More road signs in attraction sites (mentioned 4 times),

- Building a mega mall center and recreation center for kids (mentioned 4 times),

- More rest houses and tourist stops on the roads to Salalah from GCC countries (mentioned 3 times),

- More upscale hotels and hotel apartments (mentioned 2 times),

- More services in attraction sites (mentioned 2 times), - If possible, daily spraying for insects in natural springs sites (mentioned 2 times),

- Provide information materials and souvenirs shops in each attraction site and in accommodation places (mentioned 2 times),

- Do not mind paying entry fees for attraction sites and toll for roads maintenance (mentioned 2 times),

- More intensive advertising about Salalah, specially in Kuwait, and other GCC countries (mentioned 2 times), - Good shopping places,

- Festival centers to be developed,- - Bus services - - -connecting places to be started,

- Great place to enjoy,

- Greater emphasis on apartment hotels classifications, 
- Holding folklore shows at attraction sites,

- More parking in attraction sites,

- The natural beauty of salalah matches any other natural parks in USA, Canada, Australia, and the majority of European countries visited,

- Prohibiting singing and music in festival sites and raising religious and cultural awareness instead,

- Hotel apartments and villas should offer laundry facilities,

- Offer grills for barbecue in natural parks,

- Offer car maintenance and tire service stations on roads to Salalah,

- More police patrol on roads to Salalah,

- More security and safety in mountain sites,

- Accommodation prices are so high,

- Greater emphasis on sanitation and health issues regarding eating places,

- Placing large disposal containers in all attraction sites,

- Great hospitality and courteous treatment from all,

- Offer guidance services on-site,

- Building a large international hospital for remedy instead of traveling abroad for health care,

- Regulating taxi fees,

\section{Conclusion}

This study provides a visitor profile for local, regional, and international travelers to Salalah as a whole. The results confirm the significance of regional markets to Salalah tourism specially visitors from the neighboring GCC countries and suggest that there is a potential for additional benefits. By profiling the typical local, regional, and international visitor to Salalah, marketing efforts can be refined and become more effective. It is recommended to profile local, regional, and international visitors on an annual basis in order to evaluate the Salalah Tourism Authority marketing strategies and determine visitors' trends.

\section{References}

1. Euromonitor. 2007. Travel and Tourism in Oman. www.euromonitor.com/travel-and-tourism-inoman/report: Accessed on 15 ${ }^{\text {th }}$ June, 2007.

2. Mathieson, A. and Wall G. 1992. Tourism: Economic, Physical, and Social Impacts. Pearson Education Limited, Essex, England.

3. Salalah, 2013. Ministry of Information. The Governorate of Dhofar. www.omanet.om/english/ regions/dhofar1.asp?cat=reg\#Wilayat $\% 20$ Muscat: Accessed on 30 ${ }^{\text {th }}$ December, 2013.

4. Wahab, S. E. 1975. Tourism Management. Tourism International Press, London. 
Figure (1): Levels of Education of Visitors to Salalah

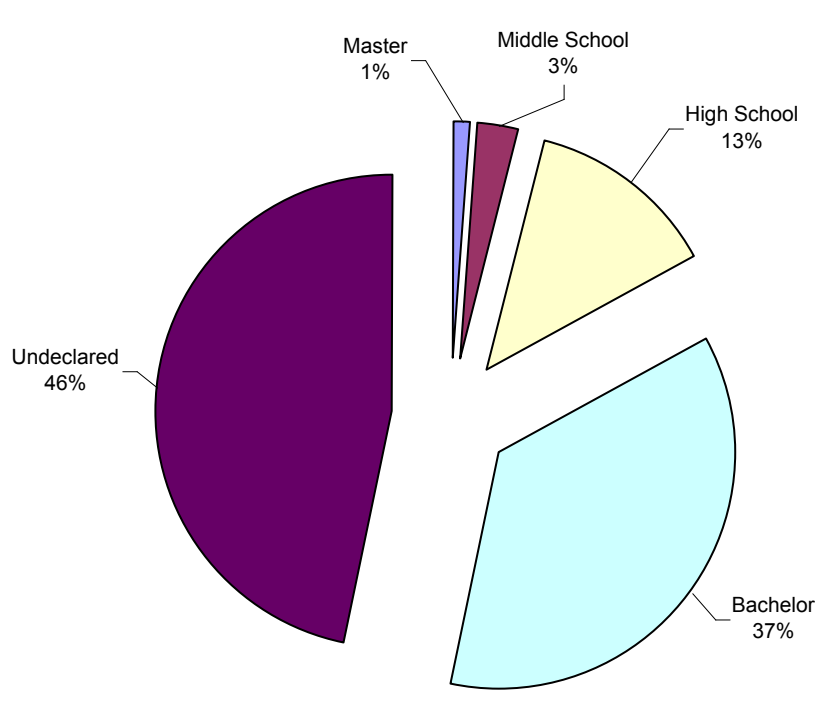

Figure (2): Ages of Visitors to Salalah

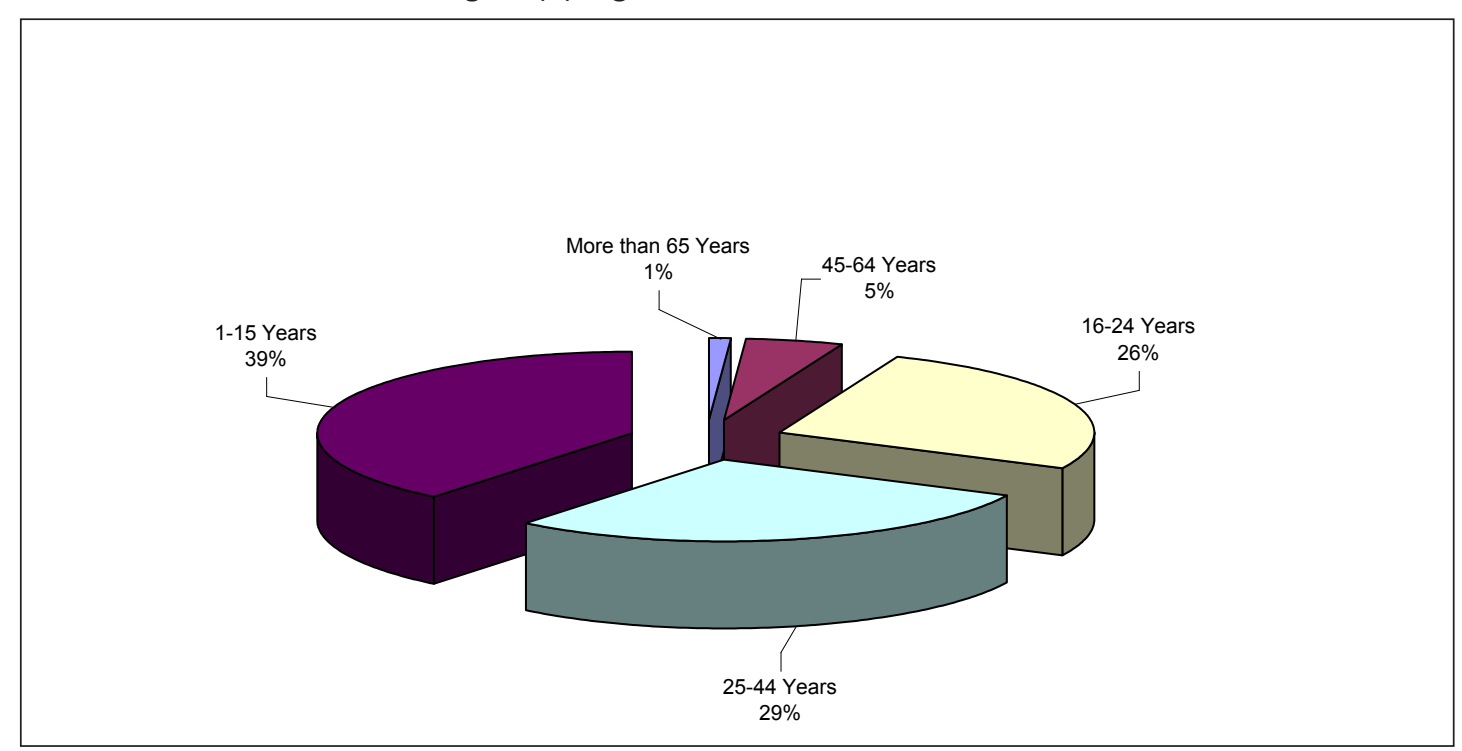

Figure (3): Purpose of Visit to Salalah

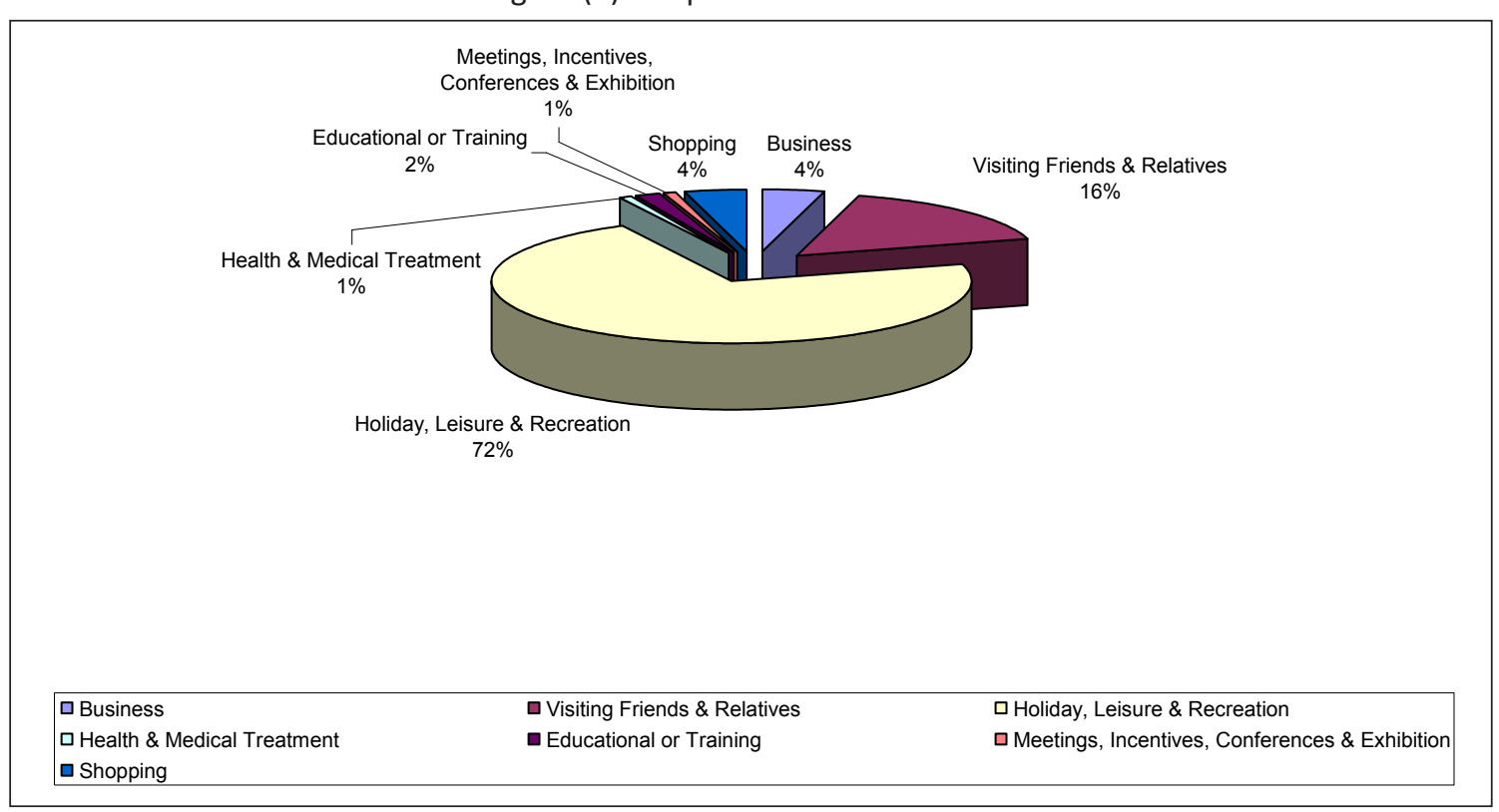


Figure (4): Trip Planning Horizon

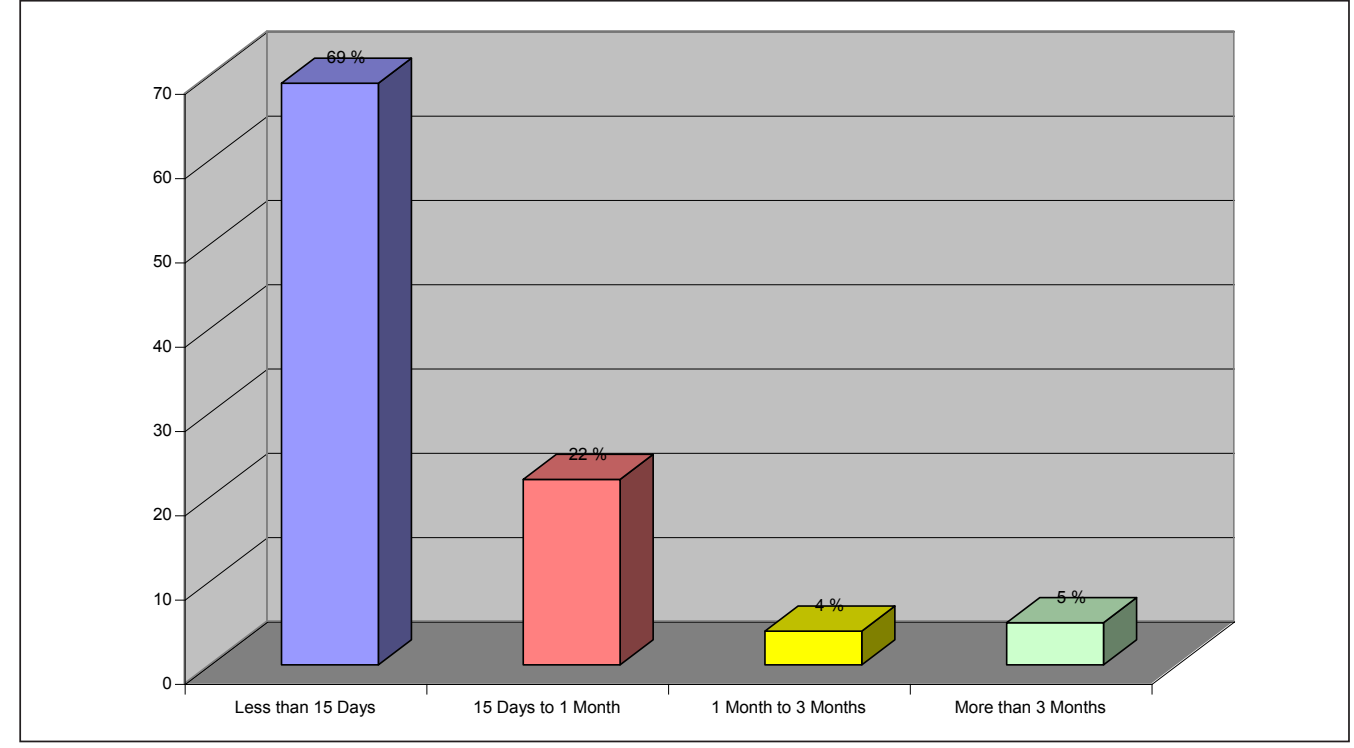

Figure (5): Length of Stay in Salalah

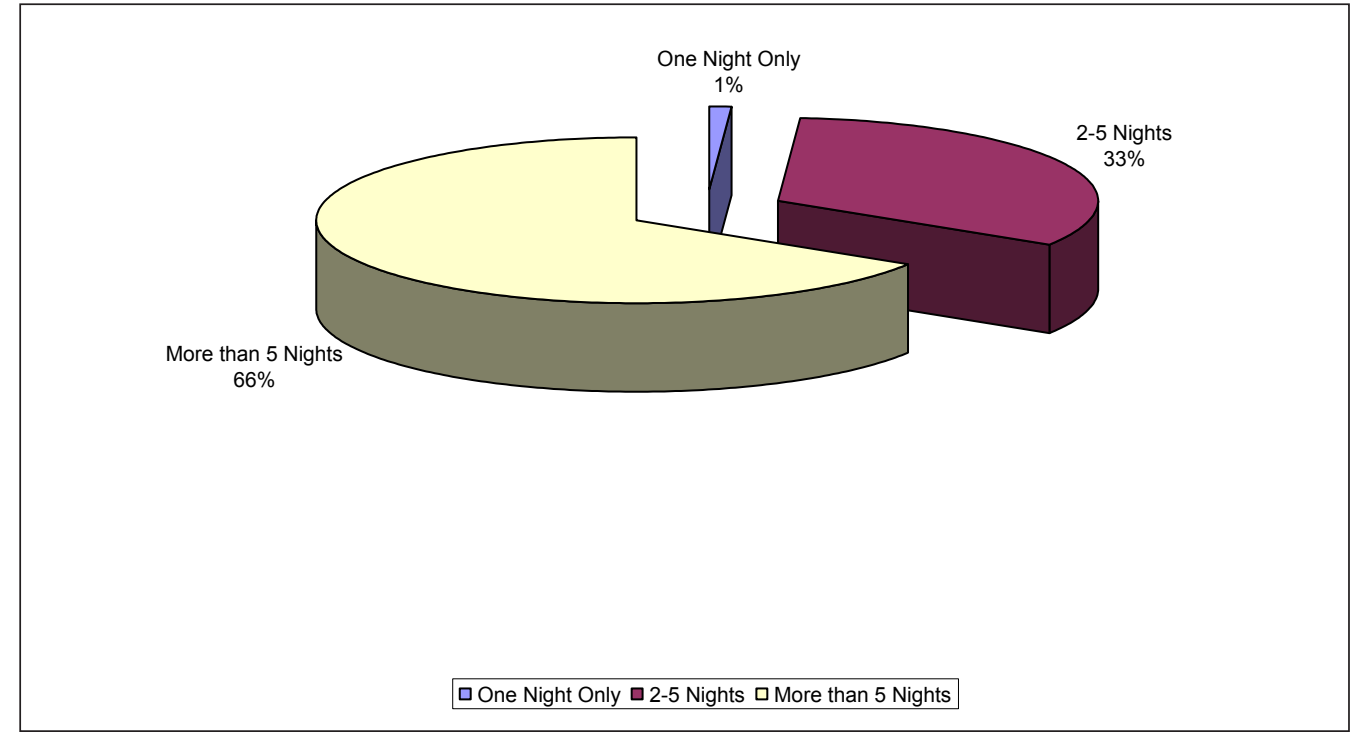

Figure (6): Types of Reservations to Salalah

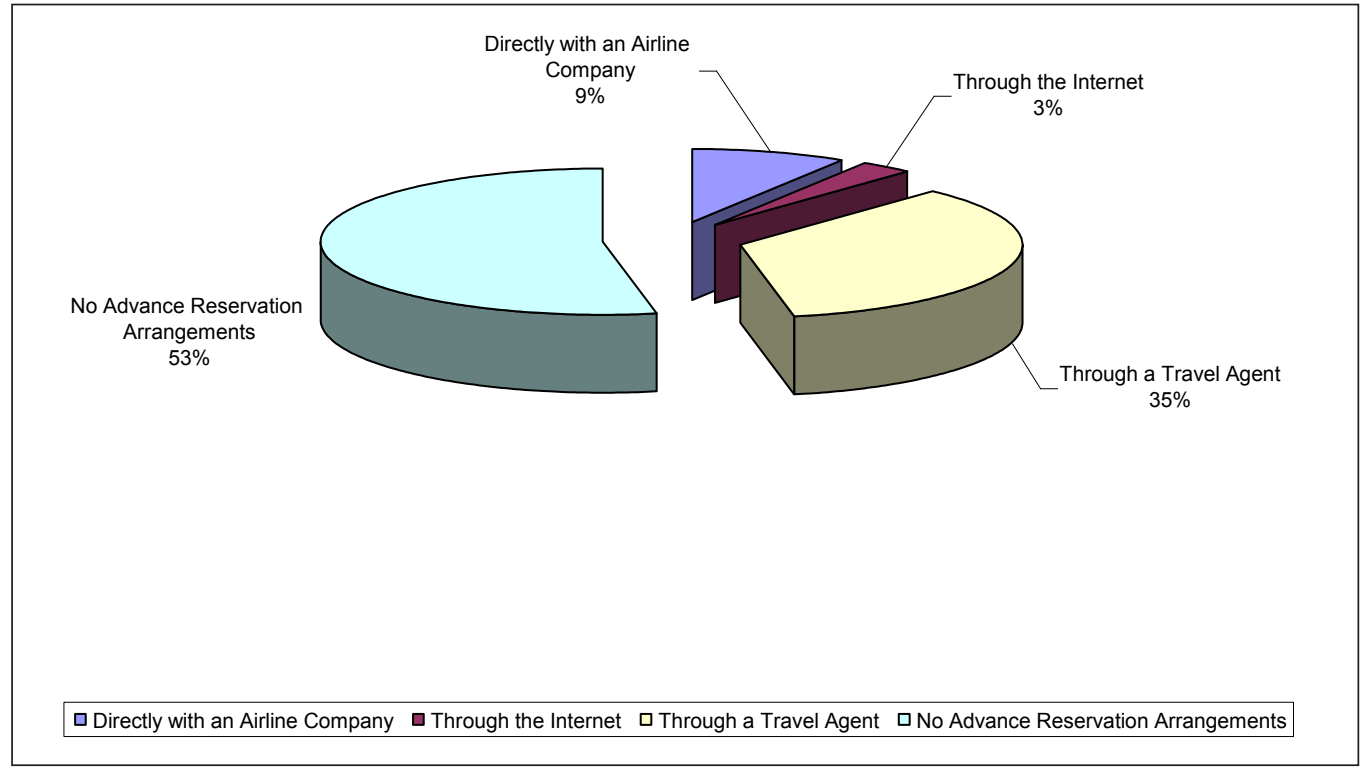


Figure (7): Means of Transportation to Salalah

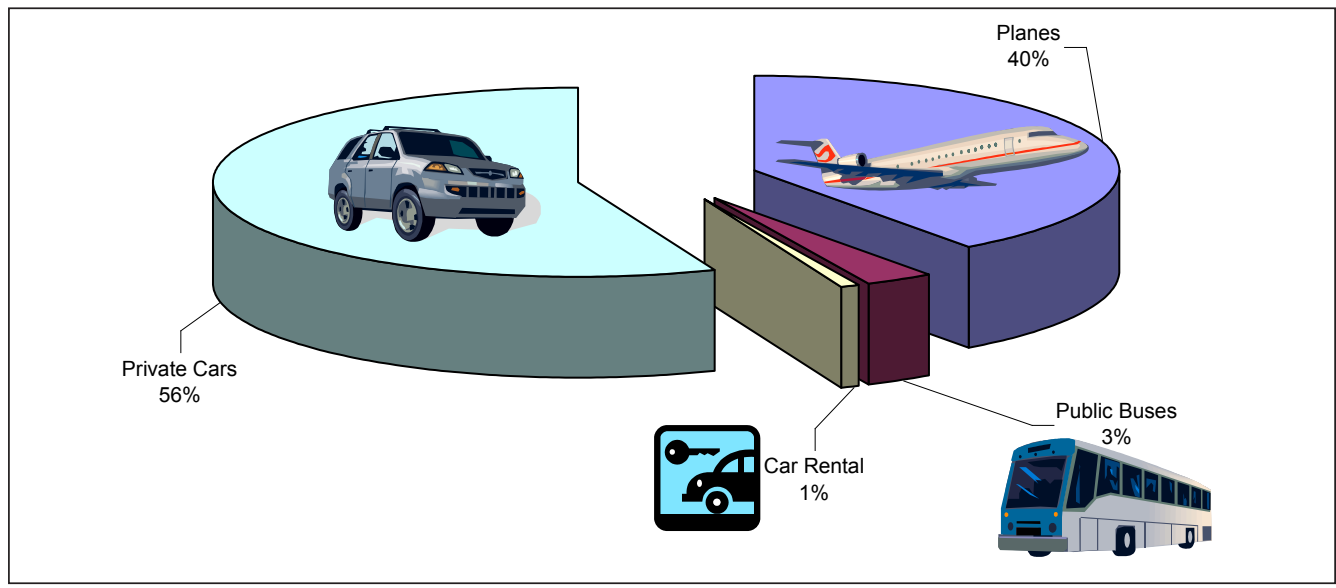

Figure (8): Types of Accommodation Used by Visitors to Salalah

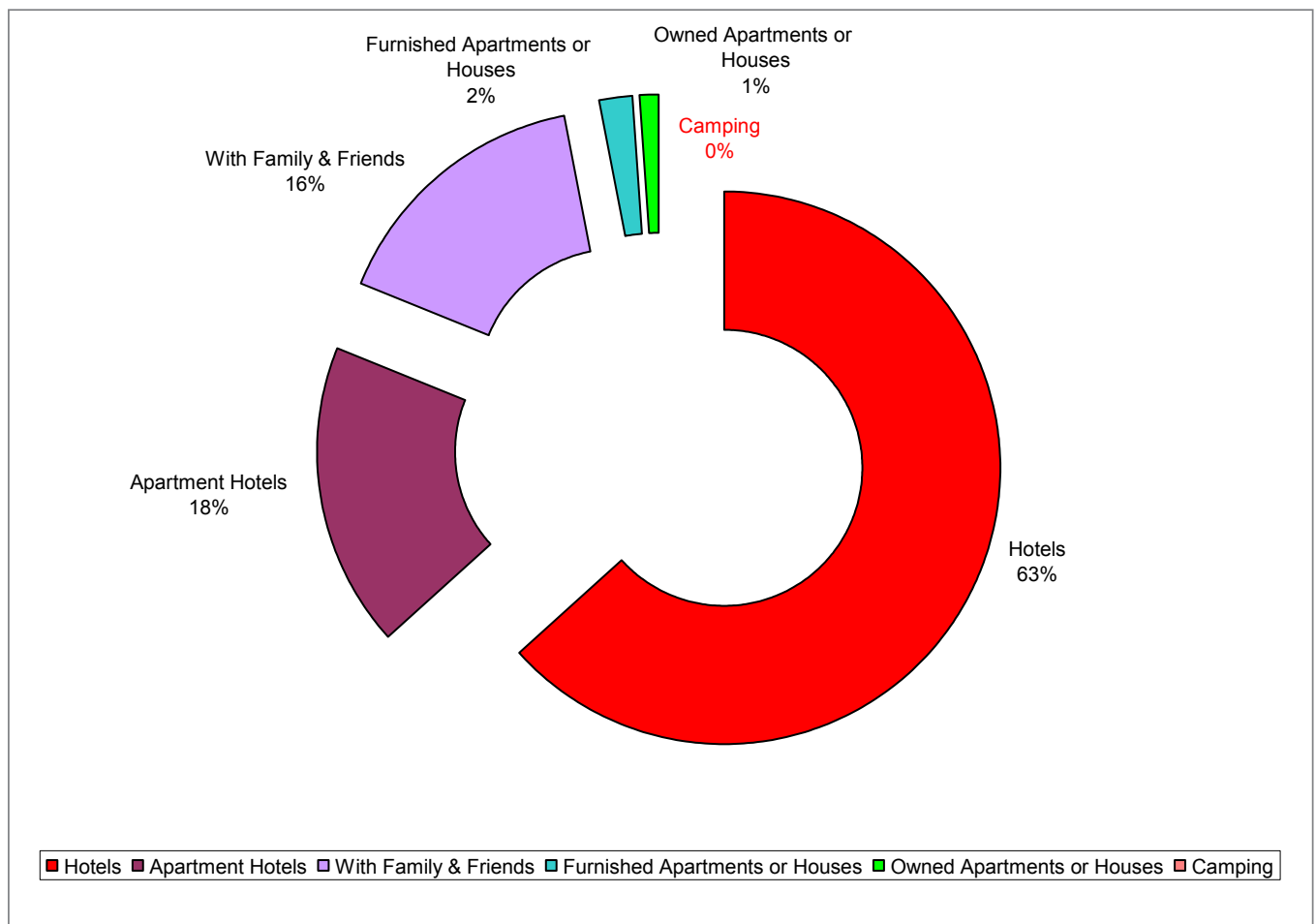

Figure (9): Visitors Activities in Salalah

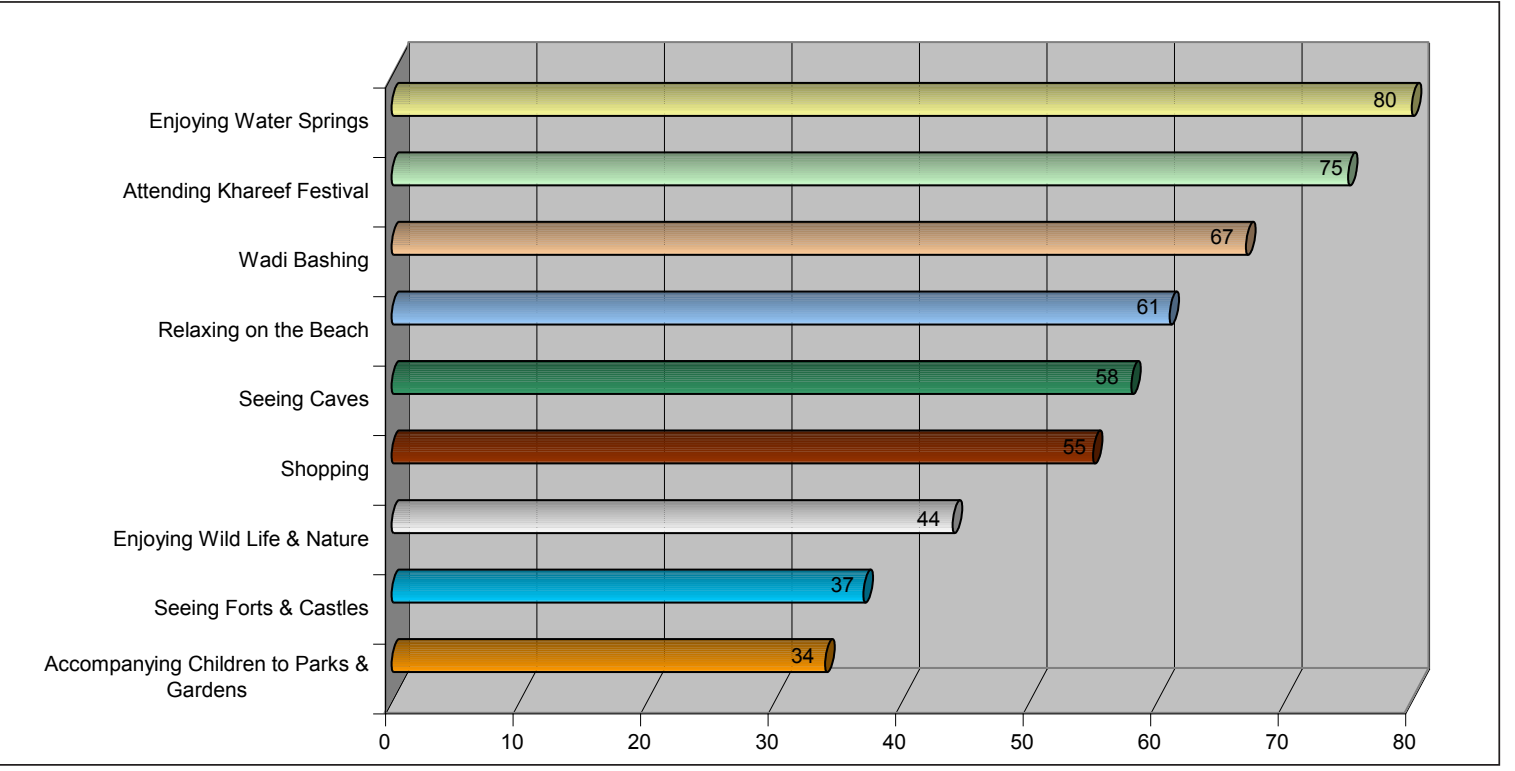


Figure (10): Sources of Information Obtained by Visitors about Salalah

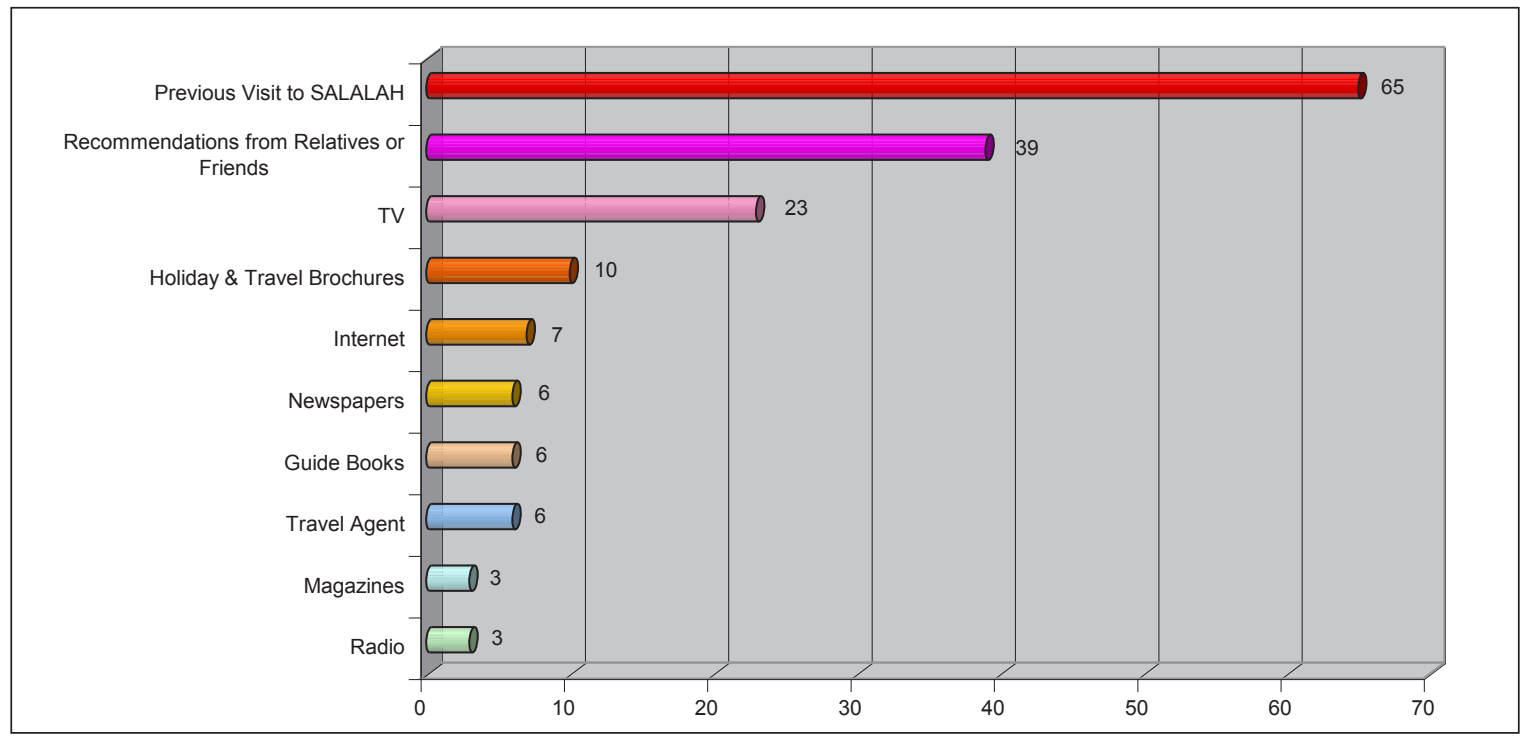

Figure (11): Segmentation of Visitors to Salalah

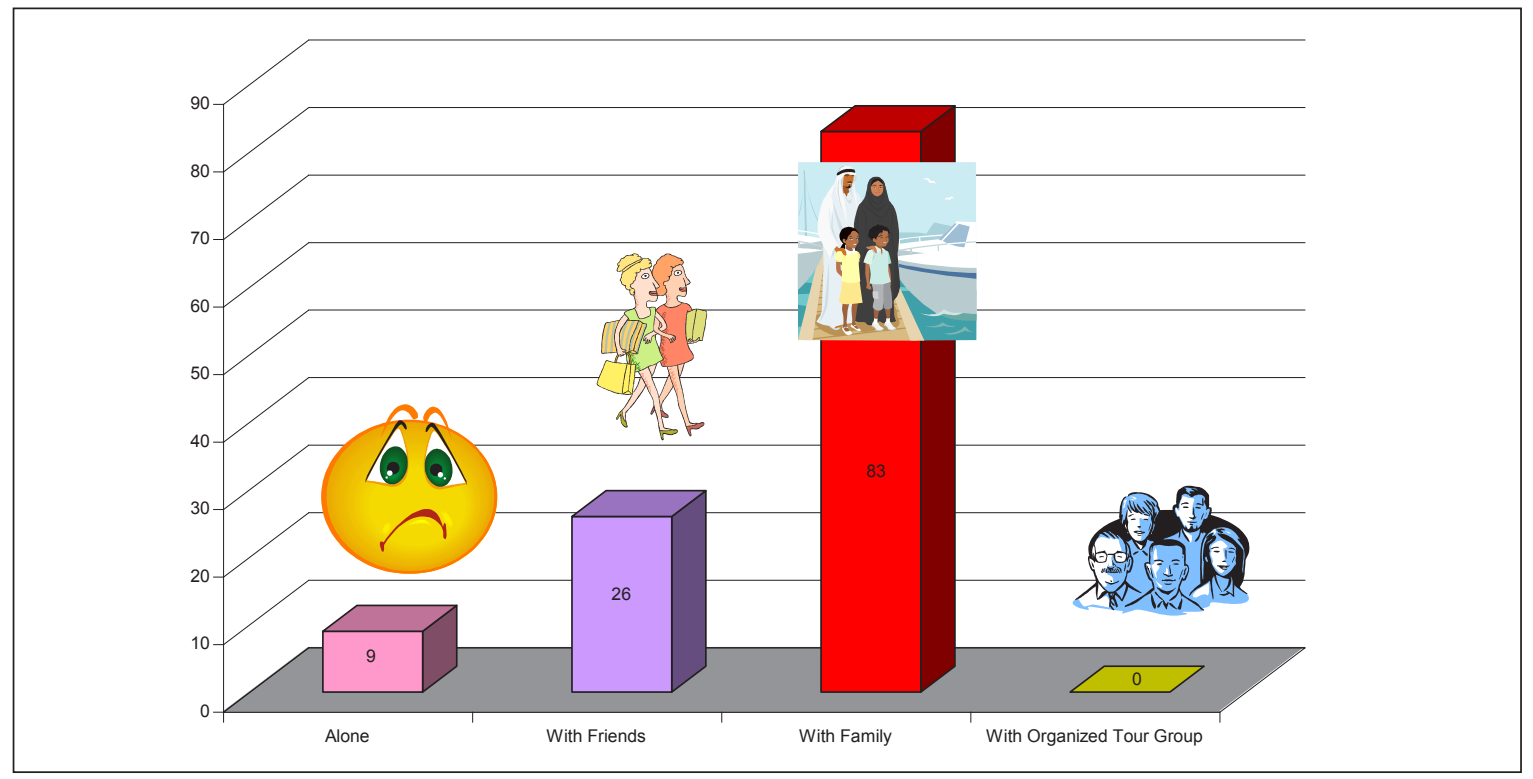

Figure (12): Factors Affecting the Decision to Travel to Salalah

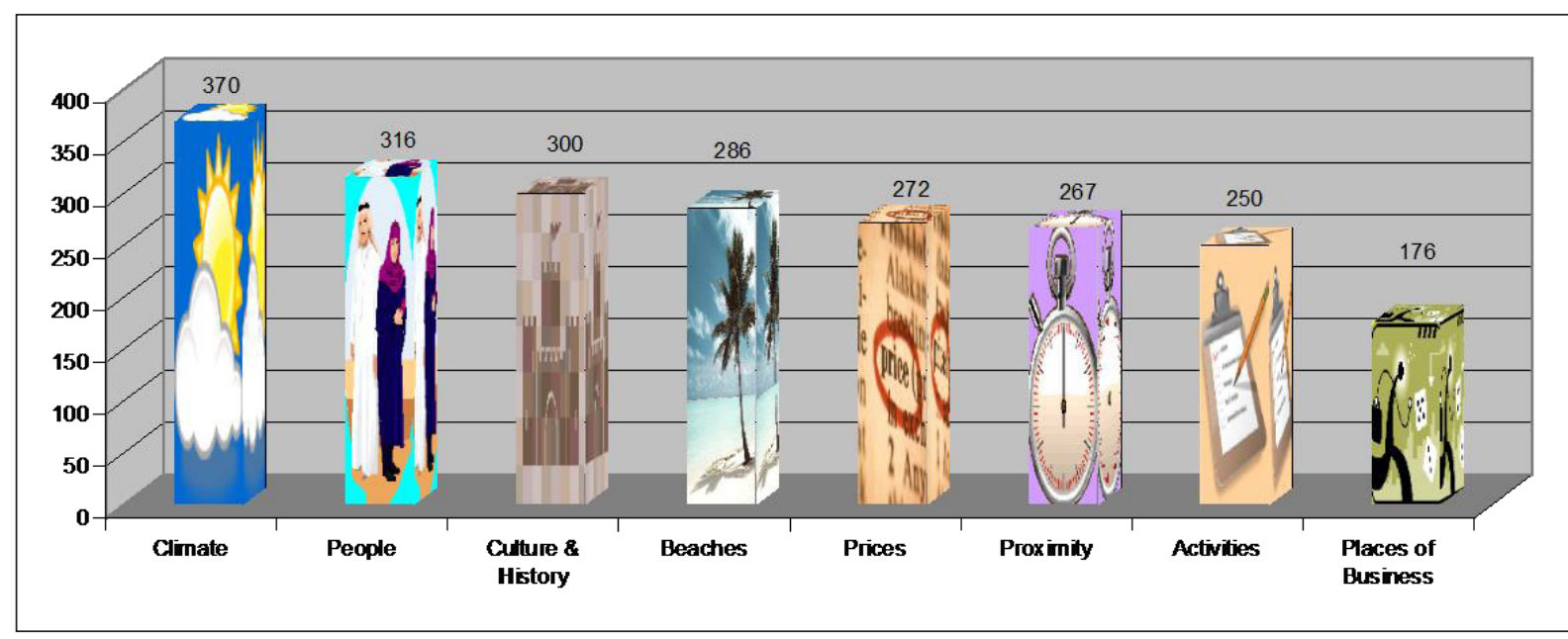


Figure (13): Rating the Salalah Experience

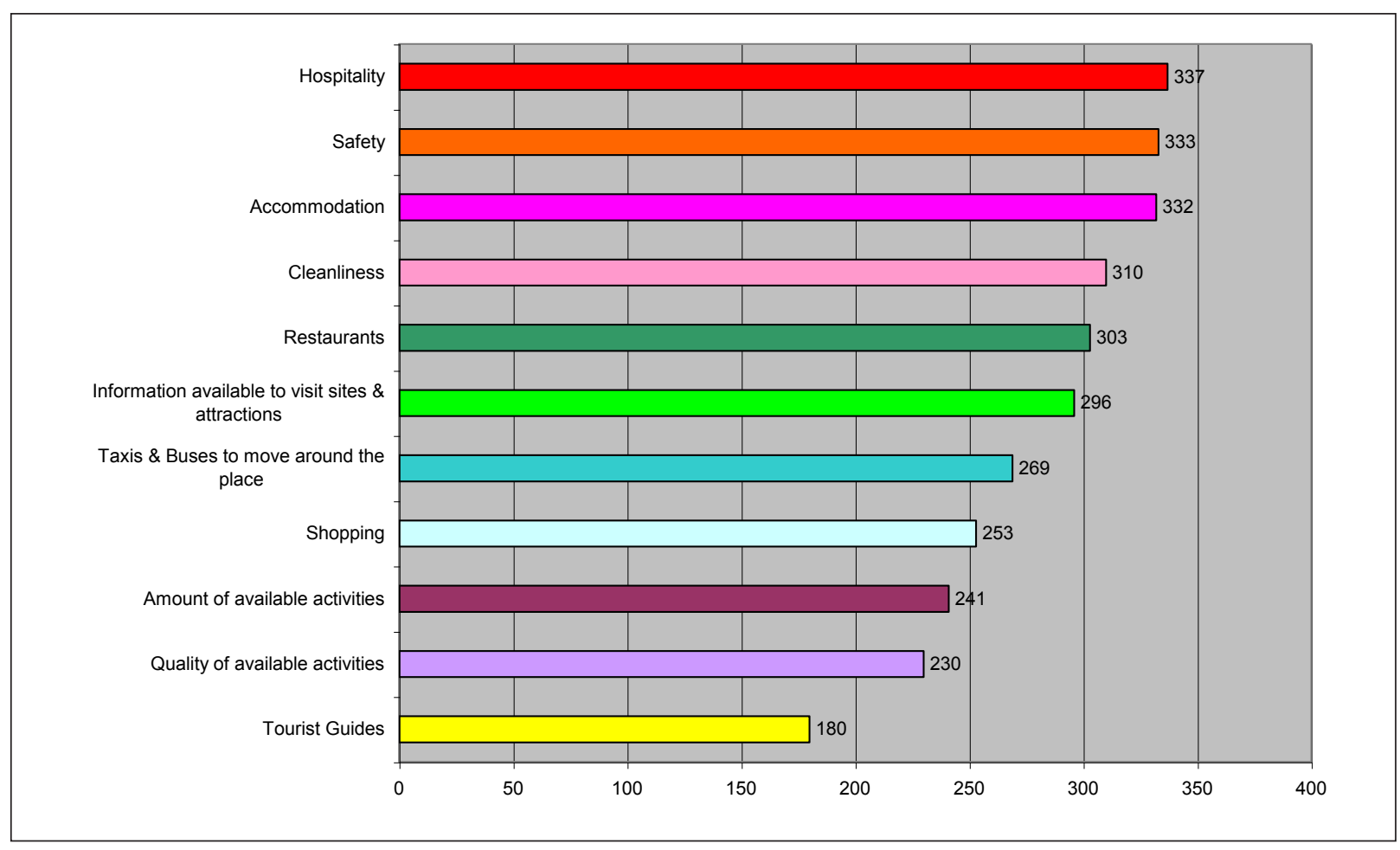

Figure (14): Nationality of Visitors to Salalah

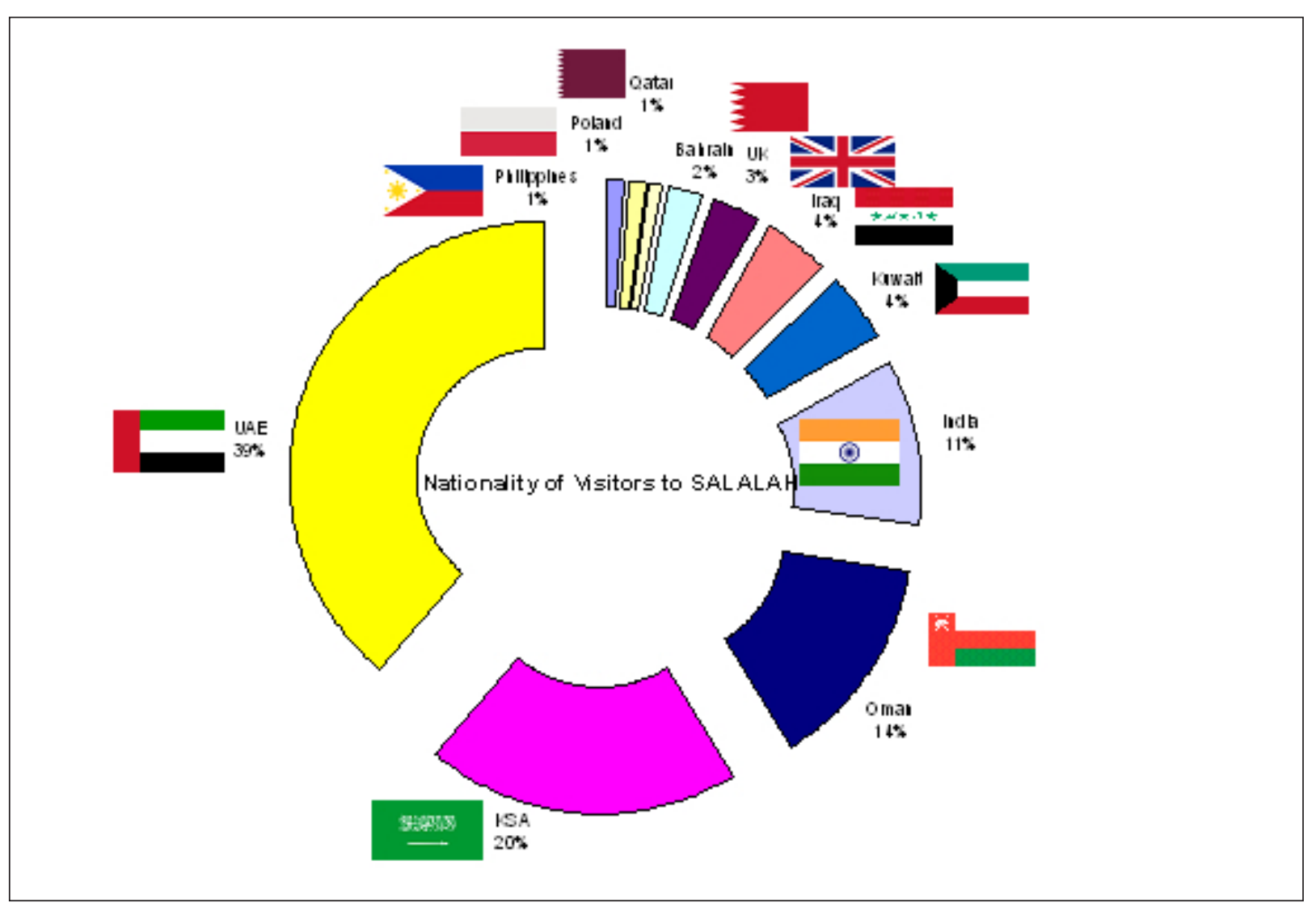


Figure (15): Current Place of Residence of Visitors to Salalah

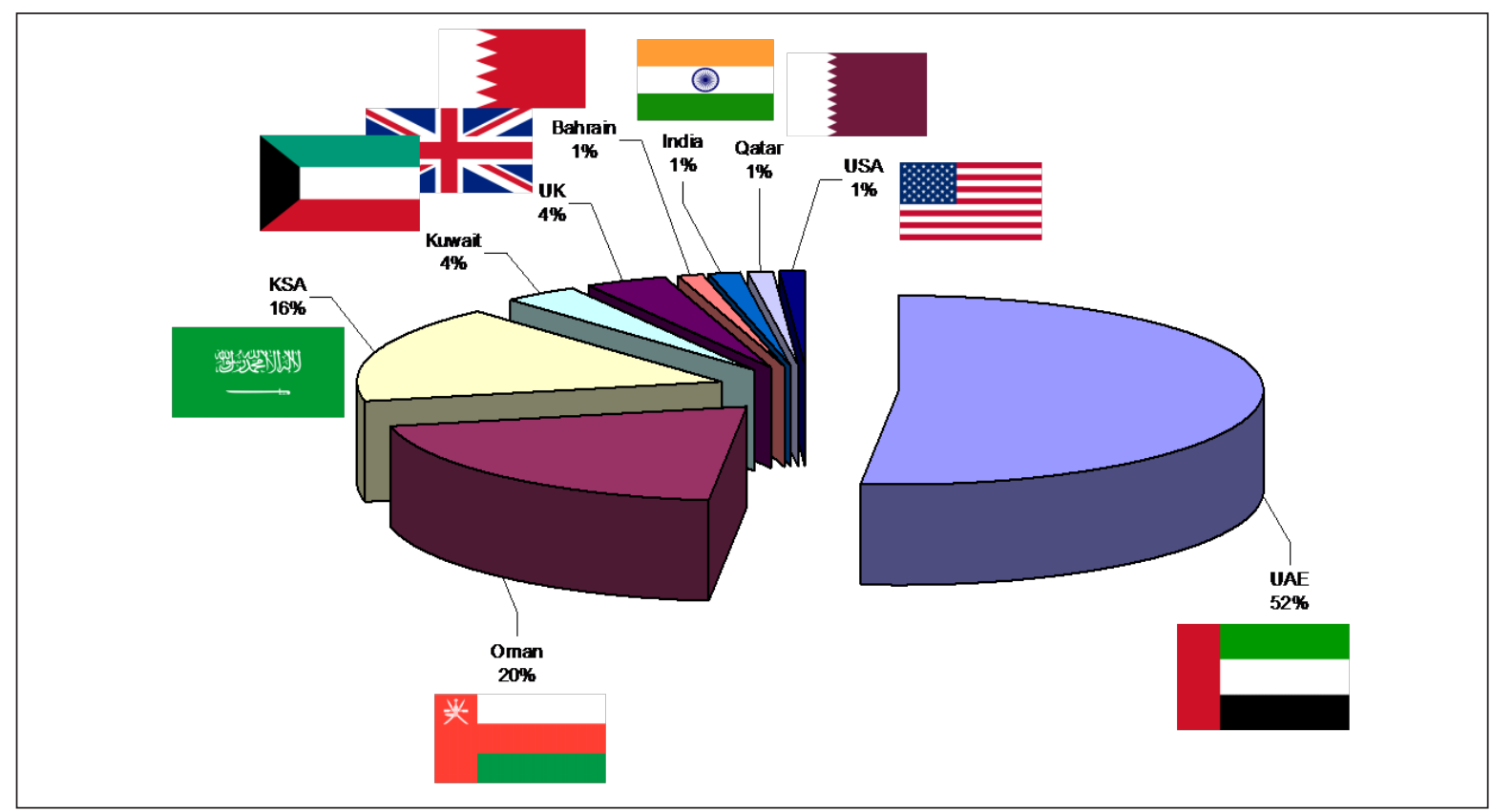

Figure (16): Levels of Visitors Satisfaction with Salalah

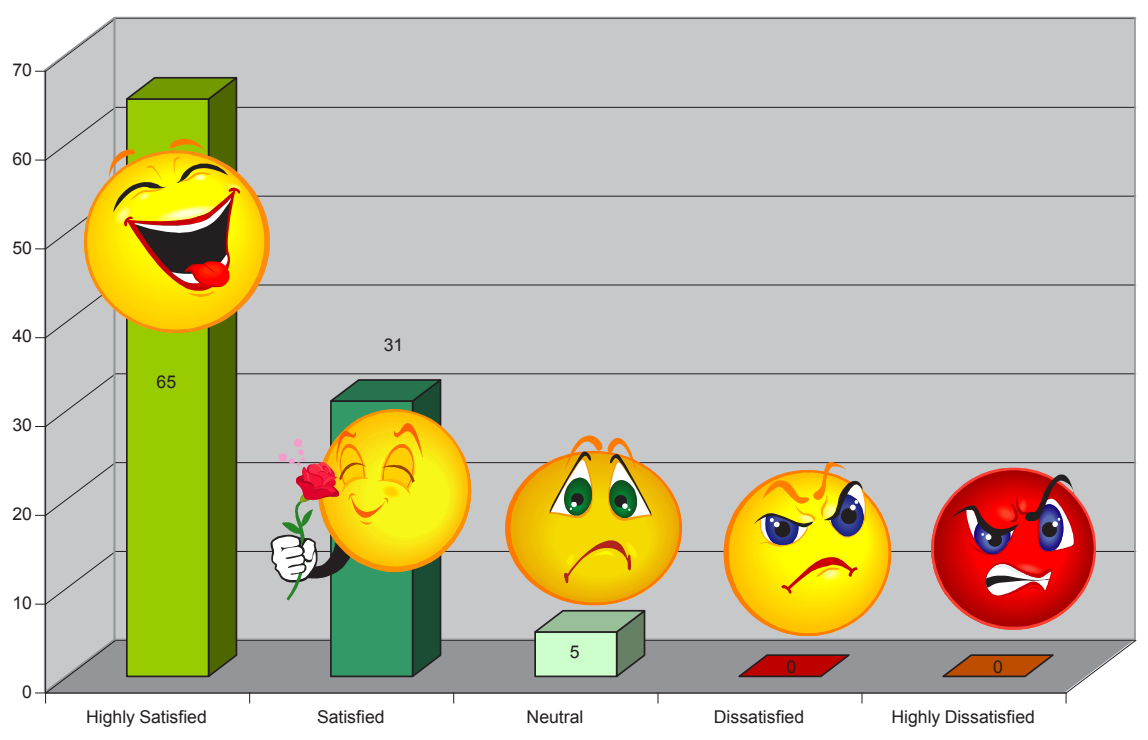

Figure (17): Are You Planning to Come Back to Salalah?

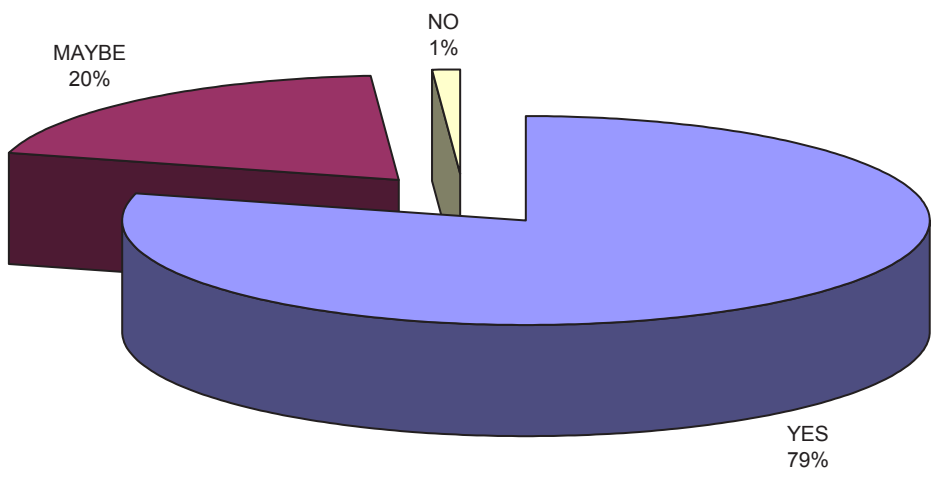


Figure (18): Would You Recommend Salalah to Anybody?

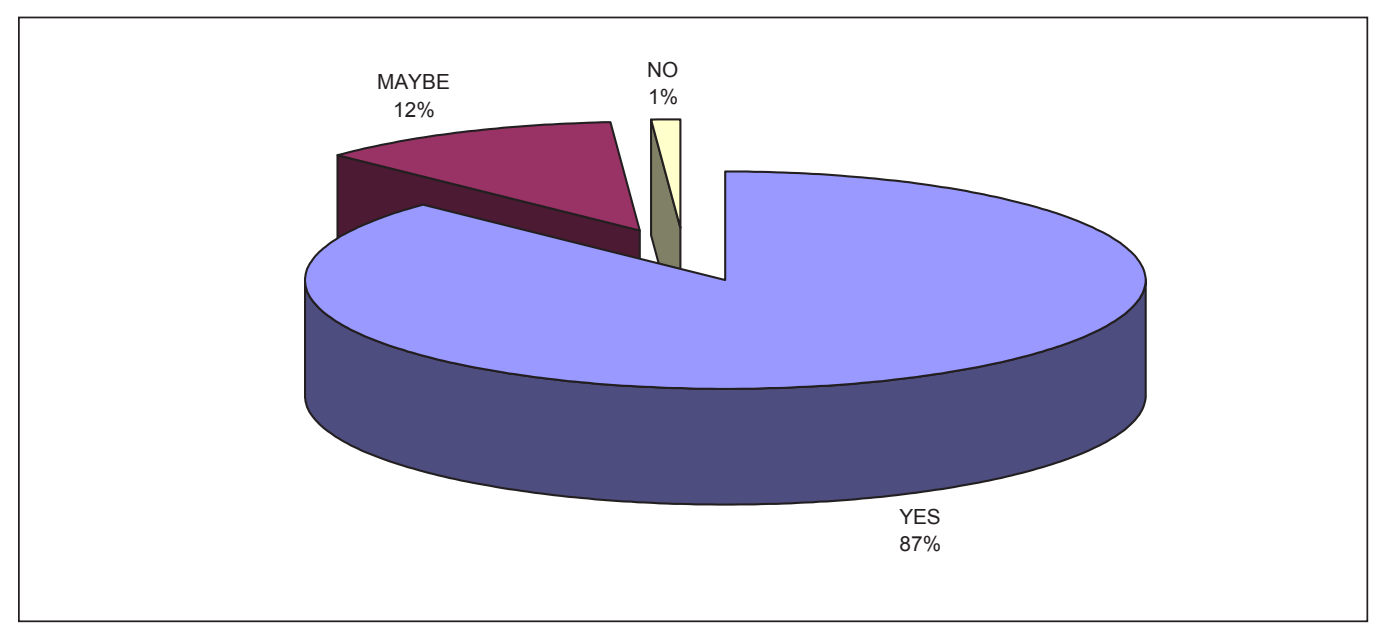

